\title{
Quantifying the Uncertainty in Historical and Future Simulations of Northern Hemisphere Spring Snow Cover $\mathscr{0}$
}

\author{
ChaD W. THACKeray AND Christopher G. Fletcher \\ Department of Geography and Environmental Management, University of Waterloo, Waterloo, \\ Ontario, Canada \\ LAWRENCE R. MUDRYK \\ Department of Physics, University of Toronto, Toronto, Ontario, Canada \\ CHRIS DERKSEN \\ Climate Research Division, Environment and Climate Change Canada, Downsview, Toronto, \\ Ontario, Canada
}

(Manuscript received 26 April 2016, in final form 29 August 2016)

\begin{abstract}
Projections of twenty-first-century Northern Hemisphere (NH) spring snow cover extent (SCE) from two climate model ensembles are analyzed to characterize their uncertainty. Phase 5 of the Coupled Model Intercomparison Project (CMIP5) multimodel ensemble exhibits variability resulting from both model differences and internal climate variability, whereas spread generated from a Canadian Earth System Model-Large Ensemble (CanESM-LE) experiment is solely a result of internal variability. The analysis shows that simulated 1981-2010 spring SCE trends are slightly weaker than observed (using an ensemble of snow products). Spring SCE is projected to decrease by $-3.7 \% \pm 1.1 \%$ decade $^{-1}$ within the CMIP5 ensemble over the twenty-first century. SCE loss is projected to accelerate for all spring months over the twenty-first century, with the exception of June (because most snow in this month has melted by the latter half of the twenty-first century). For 30-yr spring SCE trends over the twenty-first century, internal variability estimated from CanESM-LE is substantial, but smaller than intermodel spread from CMIP5. Additionally, internal variability in NH extratropical land warming trends can affect SCE trends in the near future $\left(R^{2}=0.45\right)$, while variability in winter precipitation can also have a significant (but lesser) impact on SCE trends. On the other hand, a majority of the intermodel spread is driven by differences in simulated warming (dominant in March-May) and snow cover available for melt (dominant in June). The strong temperature-SCE linkage suggests that model uncertainty in projections of SCE could be potentially reduced through improved simulation of spring season warming over land.
\end{abstract}

\section{Introduction}

Seasonal snow cover is a crucial component of the climate system, with major impacts on the surface energy budget and water balance. At its peak, snow covers approximately $47 \times 10^{6} \mathrm{~km}^{2}$ of Northern Hemisphere $(\mathrm{NH})$

Supplemental information related to this paper is available at the Journals Online website: http://dx.doi.org/10.1175/JCLI-D-16-0341.s1.

Corresponding author address: Chad W. Thackeray, Department of Geography and Environmental Management, University of Waterloo, 200 University Ave. W, Waterloo, ON N2L 3G1, Canada.

E-mail: cwthacke@uwaterloo.ca land (about 40\% of the land area) each year (Hall 1988; Robinson and Frei 2000). The reflective properties of snow mean that it has a very strong influence on land surface albedo, controlling its seasonal evolution. This high albedo has a cooling influence on climate, with the contribution from terrestrial snow to cryospheric cooling being roughly equal to that of sea ice (Flanner et al. 2011). Furthermore, snow cover can indirectly impact atmospheric circulation (Fletcher et al. 2009; Cohen et al. 2012). Water resources across most $\mathrm{NH}$ extratropical (poleward of $30^{\circ} \mathrm{N}$ ) land areas rely on natural water storage provided by snowpack (Diffenbaugh et al. 2013), with approximately one-sixth of Earth's population dependent on snowmelt for a portion of their water supply (Barnett et al. 2005; Mankin 
et al. 2015). Earlier spring snowmelt across the western United States has been linked to increased summer heat extremes (Diffenbaugh et al. 2005; Hall et al. 2008) and wildfires (Westerling et al. 2006). Snow cover also has a low thermal conductivity, meaning that it can have an insulating effect on soil temperatures, with important impacts on permafrost extent (Zhang 2005; Zhang et al. 2008; Lawrence and Slater 2010). Variability in snow conditions also has implications for travel and tourism (e.g., Scott et al. 2008). It is crucial, therefore, that we understand how projected warming will affect snow cover.

Extensive climatological snow cover, and relatively high insolation, make the climate system most sensitive to snow and albedo changes during spring (changes during fall and winter are less important because of decreasing insolation across the NH) (Ingram et al. 1989; Hall 2004). Snow albedo feedback (SAF) peaks during March-May (Qu and Hall 2014). Numerous observational studies have shown that Northern Hemisphere spring snow cover extent (SCE) has been decreasing rapidly over recent decades (Groisman et al. 1994; Déry and Brown 2007; Flanner et al. 2009; Brown et al. 2010; Brown and Robinson 2011; Hernández-Henríquez et al. 2015). Most of the loss in snow occurs over "temperaturesensitive regions," where changes in SCE are closely linked to temperature variability (Karl et al. 1993; Déry and Brown 2007). March-April SCE is decreasing at a rate of $-3.4 \% \pm 1.1 \%$ decade $^{-1}$ (1979-2005) (Brown and Robinson 2011), and June SCE has decreased by approximately $-18 \%$ decade $^{-1}$ from 1979 to 2014 (Derksen et al. 2015). This rate of decline in SCE exceeds the well-publicized declining trend in September Arctic sea ice $\left(-13 \%\right.$ decade $\left.^{-1}\right)$. It should be noted that the absolute areal SCE loss in March-April is comparable to that observed during June because there is much less snow-covered area in June (section 3a).

By contrast, the suite of climate models contributing to phase 5 of the Coupled Model Intercomparison Project (CMIP5) simulate March-April SCE trends roughly one-third as large as observed for the same time period $\left(-1.0 \% \pm 0.3 \%\right.$ decade $\left.^{-1}\right)$ (Brutel-Vuilmet et al. 2013). This underestimation, also found for the CMIP3 models (Roesch 2006), is associated with underestimated extratropical spring warming (Brutel-Vuilmet et al. 2013). Derksen and Brown (2012) and Mudryk et al. (2014) illustrate other aspects of the observed trends that are not well captured by general circulation models (GCMs).

Northern Hemisphere SCE is expected to continue decreasing under future warming. Several studies over the past 30 years have utilized GCMs to show that SCE decreases substantially in a doubled- $\mathrm{CO}_{2}$ climate (Manabe and Wetherald 1987; Boer 1993; Essery 1997). More recently, the Intergovernmental Panel on Climate
Change (IPCC) Fifth Assessment Report (AR5) stated that early spring (March-April) SCE is likely to decrease by $7 \%-25 \%$ (from RCP2.6 to RCP8.5 scenario) by 2100 (Collins et al. 2013; Brutel-Vuilmet et al. 2013). However, this projection was only assigned a medium confidence level because of a large intermodel spread, and a lack of sophistication in the representation of snow processes in many models (e.g., single-layer snowpack, and snow schemes that assume an equal distribution of snow mass across a grid cell; Collins et al. 2013; Slater et al. 2001). Furthermore, no projections of SCE were provided for late spring (May-June), when snow cover is largely restricted to the Arctic, but still represents a significant area (mean 1982-2002 Arctic SCE for May and June was 11.0 and $3.9 \times 10^{6} \mathrm{~km}^{2}$, respectively; Brown et al. 2010). The Arctic has experienced the greatest warming in recent decades (Bekryaev et al. 2010), and that trend is expected to continue due to positive feedback mechanisms such as the lapse rate and albedo feedbacks (Pithan and Mauritsen 2014) with implications for spring snow cover.

CMIP (Meehl et al. 2007; Flato et al. 2013) and Snow Models Intercomparison Project (SnowMIP; Etchevers et al. 2004; Rutter et al. 2009) studies have demonstrated that a large intermodel spread exists when simulating snow properties (extent and mass). This limits our confidence in future projections, and is likely to be caused by a combination of internal climate variability and model uncertainty (intermodel variability among GCMs in response to the same forcing) from physical processes that are either missing or oversimplified (Hawkins and Sutton 2011). For example, simulated snow mass (and similarly SCE) is sensitive to different parameterizations for snowfall, albedo, snow-vegetation masking, and snow cover fraction (see Slater et al. 2001; Bartlett et al. 2006; Dai 2008; Rutter et al. 2009; Essery et al. 2013).

Internal climate variability arises primarily from naturally occurring nonlinear atmospheric and oceanic processes, and their interactions (Deser et al. 2012b; Kay et al. 2015). The processes can be nearly instantaneous, or take several years (Hegerl et al. 2007). Internal variability influences projected regional trends in temperature and precipitation, even in the presence of a background trend in $\mathrm{CO}_{2}$ forcing (Hawkins and Sutton 2009, 2011; Deser et al. 2012b), both of which are crucial factors for future winter snow accumulation patterns (Räisänen 2008; Krasting et al. 2013; Mankin and Diffenbaugh 2015; Shi and Wang 2015). Therefore, it is likely that internal climate variability could also influence projected trends for spring SCE.

The primary goal of this work is to investigate the spread in twenty-first-century changes to spring snow cover as projected by the CMIP5 suite of climate models. 
We use the recent past to help understand the spread in trend strength between simulations and observations. We also seek to determine the influences of both internal variability and model uncertainty in these simulations, to answer the following research questions: (i) What impact does the representation of snow-climate processes [e.g., the sensitivity of snow cover to warming (henceforth, snowmelt sensitivity)] have on simulations of SCE? (ii) What are the respective roles of temperature and precipitation changes in governing SCE trends? The data and methods are described in section 2. In section 3 , we present historical and projected SCE trends, and diagnose the respective roles of model uncertainty and internal variability. Last, section 4 highlights the key findings of this research and provides a discussion of how our findings relate to previous research.

\section{Data and methods}

\section{a. Climate model data}

We use monthly mean output from the suite of historical (1850-2005) and future (2006-2100) simulations from the CMIP5 archive (Taylor et al. 2012; http://cmip-pcmdi.llnl. gov/cmip5/) to evaluate snow cover in 15 models (Table 1 ). Only models that archived the variable snc [snow cover fraction (SCF)] are included in this analysis so as to avoid introducing uncertainty through the estimate of SCE from snow water equivalent (snow mass, the variable snw) as done in previous studies (e.g., Roesch 2006). Future snow cover projections are forced using the RCP8.5 scenario because it most closely resembles the observed emissions pathway over the past decade (Peters et al. 2013). We use all available realizations $(n=1, \ldots, 10)$ from each of the 15 CMIP5 models for a total of 61 historical runs and 41 runs for the representative concentration pathway 8.5 (RCP8.5) scenario. We compute individual trends and averages for each realization and then take the interrealization average across each model to calculate ensemble means. These values are then used to determine the CMIP5 multimodel mean values.

We also use output (variables snc, snw, tas, and psl) from a large (50 realization) ensemble of the SecondGeneration Canadian Earth System Model (CanESM2; Arora et al. 2011). To produce the 50-member Canadian Earth System Model-Large Ensemble (CanESM-LE) 10 realizations are initiated in 1950 from each of the 5 original realizations of CanESM2 submitted to CMIP5. Each new ensemble member is perturbed by changing the seed of a random number generator used in the parameterization of radiative transfer through clouds. Following the CMIP5 design, historical forcing is applied from 1950 to 2005, followed by RCP 8.5 from 2006 to 2100. This methodology is appropriate for sampling the statistics of climate variability within CanESM2, because the initial ocean conditions down to 300-m depth have very little influence on the simulation after 5-10 years (Branstator and Teng 2012). This implies that, by the time our analysis period begins in 1981, CanESM-LE represents 50 statistically independent climate states.

As a result, CanESM-LE is used to quantify the component of internal variability within future projections from a single GCM, while the CMIP5 ensemble includes a combination of model uncertainty and internal variability. Similar large ensembles have previously been used to separate the components of future climate patterns related to forced and internal variability (Deser et al. 2012a,b; Wettstein and Deser 2014; Swart et al. 2015). Consistent with previous research (Deser et al. 2012b, 2014), we estimate the "forced response" to greenhouse gas (GHG) forcing as the ensemble mean response from all 50 realizations of CanESM-LE. As in Hawkins and Sutton (2011) we estimate the contribution of "internal variability" to each realization by subtracting the ensemble mean of a particular quantity from the values in that realization. This approach is effective when there are enough simulations so that climate noise can be sufficiently diluted (Deser et al. 2012b, 2016).

\section{b. Observational data}

Seven observation-based estimates (Table 2) are used to evaluate the CMIP5 models during recent decades (1981-2010). The use of an observational ensemble reduces the chance of incorrectly identifying a model bias due to errors in a single observational analysis. The seven observation-based estimates are derived from reanalyses, satellite data, and in situ measurements. Each dataset must have complete Northern Hemisphere coverage and a data record spanning the 1981-2010 period. Those datasets that meet this criteria are 1) the NOAA snow chart climate data record (NOAA CDR) (Brown and Robinson 2011; ftp://eclipse.ncdc.noaa.gov/cdr/ snowcover/), 2) the Brown snow cover product derived from a combination of climate station data and a simple snow model (Brown et al. 2003), 3) the combined in situ and satellite passive microwave derived Global Snow Monitoring for Climate Research (GlobSnow) SWE product (Takala et al. 2011; www.globsnow.info), 4) SWE from the Modern-Era Retrospective Analysis for Research and Applications (MERRA; Rienecker et al. 2011), 5) SWE from the European Centre for Medium-Range Forecasts (ECMWF) interim reanalysis global land surface dataset (ERA-I-Land; Balsamo et al. 2015), 6) SWE from the Global Land Data Assimilation System, version 2 (GLDAS-2), product (Rodell et al. 2004), and 7) SWE 


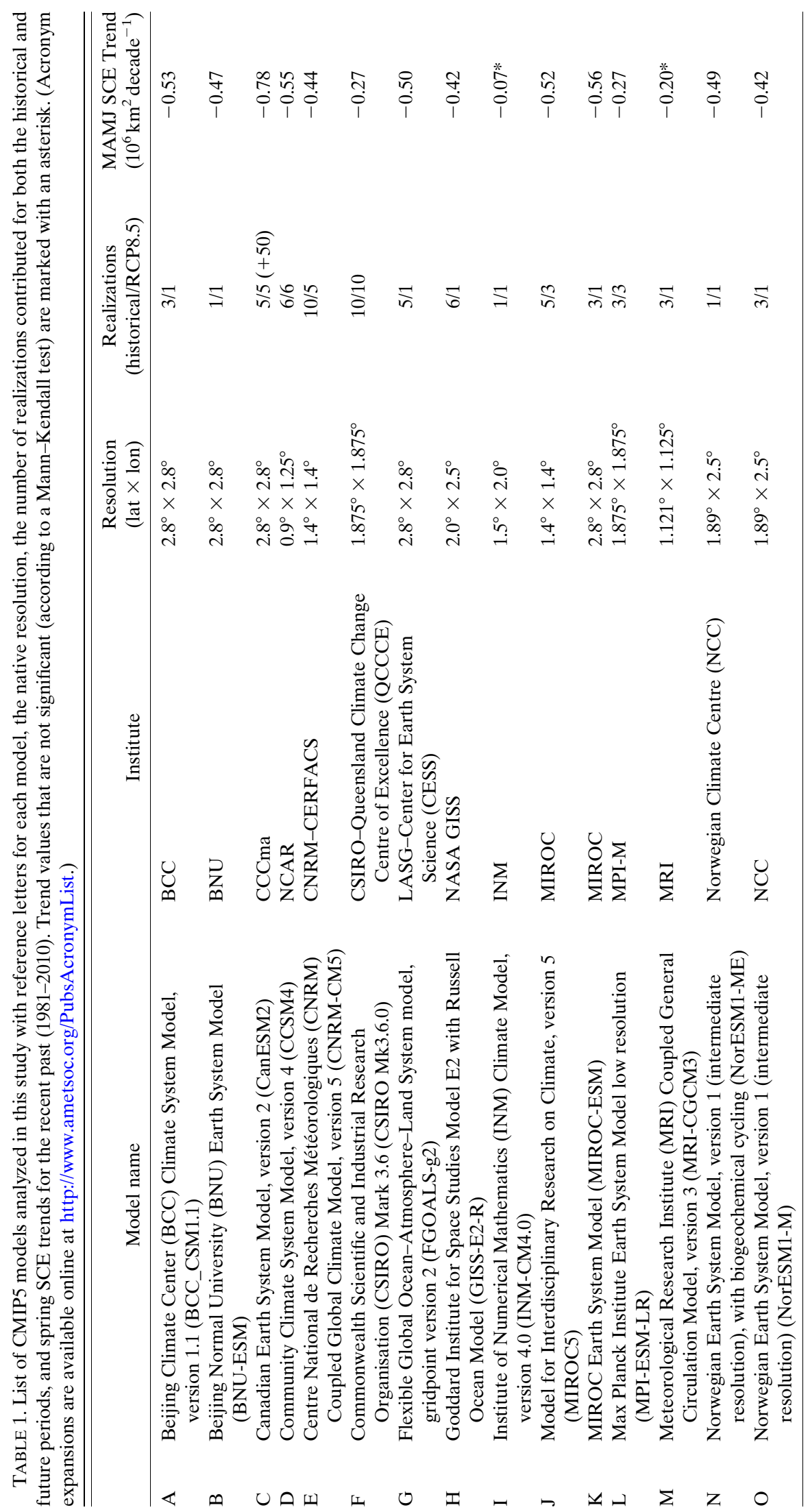


TABLE 2. List of observational-derived snow data products analyzed in this study, the native resolution, and respective climatological SCE and spring SCE trends (1981-2010). Trend values that are not significant are marked with an asterisk.

\begin{tabular}{|c|c|c|c|c|c|}
\hline & Data product & $\begin{array}{l}\text { Resolution } \\
(\text { lat } \times \text { lon })\end{array}$ & $\begin{array}{l}\text { MAMJ SCE trend } \\
\left(10^{6} \mathrm{~km}^{2} \mathrm{decade}^{-1}\right)\end{array}$ & $\begin{array}{l}\text { MAMJ percent loss } \\
\quad\left(\% \text { decade }^{-1}\right)\end{array}$ & $\begin{array}{l}\text { MAMJ mean snow } \\
\text { extent }\left(10^{6} \mathrm{~km}^{2}\right)\end{array}$ \\
\hline 1 & Brown dataset (Brown et al. 2003) & $0.75^{\circ} \times 0.75^{\circ}$ & -0.74 & -3.9 & 19.0 \\
\hline 2 & Crocus (Brun et al. 2013) & $1^{\circ} \times 1^{\circ}$ & -0.63 & -3.8 & 16.6 \\
\hline 3 & ERA-I-Land (Balsamo et al. 2015) & $0.75^{\circ} \times 0.75^{\circ}$ & -0.38 & -2.2 & 17.9 \\
\hline 4 & GLDAS-2 (Rodell et al. 2004) & $1^{\circ} \times 1^{\circ}$ & $-0.22 *$ & -1.6 & 14.1 \\
\hline 5 & GlobSnow (Takala et al. 2011) & $25 \mathrm{~km}$ & -0.55 & -3.4 & 16.2 \\
\hline 6 & MERRA (Rienecker et al. 2011) & $0.5^{\circ} \times 0.66^{\circ}$ & -0.50 & -3.3 & 15.1 \\
\hline \multirow[t]{3}{*}{7} & NOAA CDR (Brown and Robinson 2011) & $190 \mathrm{~km}$ & -0.82 & -4.2 & 19.3 \\
\hline & CMIP5 mean & - & $-0.43 \pm 0.17$ & $-2.5 \pm 1.0$ & $17.0 \pm 3.4$ \\
\hline & CanESM-LE & $2.8^{\circ} \times 2.8^{\circ}$ & $-0.62 \pm 0.18$ & $-3.0 \pm 0.9$ & $20.6 \pm 0.2$ \\
\hline
\end{tabular}

output from the snowpack model Crocus driven by ERA-Interim meteorology (Brun et al. 2013). Three of the snow products use the same atmospheric forcing data from ERA-Interim (Brown dataset, Crocus, and ERA-I-Land). However, despite this similarity, they exhibit very different SCE trends due to differences in the snow parameterizations between Crocus and HTESSEL (ERA-I-Land), while the Brown dataset only uses temperature and precipitation to force a simple snow model (Table 2).

The NOAA CDR is derived primarily from optical satellite data (Brown and Robinson 2011). This dataset provides monthly fractional snow cover, which is calculated as the percent of days per month that a grid cell is at least $50 \%$ snow covered. The Brown dataset (Brown et al. 2003) uses ground-based snow measurements and a simple snowpack model to produce SCF from daily SWE thresholds exceeding $4 \mathrm{~mm}$. The five remaining datasets (MERRA, ERA-I-Land, GLDAS-2, GlobSnow, and Crocus) were used in the SWE product intercomparison described in Mudryk et al. (2015). For these products, $\mathrm{SWE}$ is initially interpolated to a $1^{\circ} \times 1^{\circ}$ grid and SCF is then derived from daily SWE thresholds exceeding $4 \mathrm{~mm}$. The 1981-2010 time period is a shorter record than available from individual datasets (e.g., the NOAA CDR starts in 1967) but the compromise in time series length is mitigated by the advantages of a multidataset perspective, which has typically not been used in previous snow-climate studies.

An observational ensemble of temperature is used to determine spring snow extent sensitivity. We select five datasets for temperature: the Climatic Research Unit (CRU) land station temperature database (Jones et al. 1999; 2012), the Goddard Institute for Space Studies (GISS) surface temperature analysis (Hansen et al. 2010), the National Climatic Data Center (NCDC) temperature product (Smith et al. 2008), and the National Centers for Environmental Prediction (NCEP) surface and 2-m (NCEP2m) temperature datasets (Kalnay et al. 1996).

\section{c. Analysis methods}

The CMIP5 models output data at a variety of resolutions $\left(1^{\circ}-3^{\circ}\right.$ grid boxes), and to account for this we must create a consistent land-sea mask such that land area biases are reduced [particularly in the Canadian Arctic Archipelago (CAA), where many narrow channels may not be resolved at coarser resolution; Laliberté et al. 2016]. For each CMIP5 model a land-sea mask extracted from the MERRA product is remapped to the native model resolution to isolate simulated NH landonly snow cover and temperature data. This ensures that we reduce discrepancies in the amount of land area between models (mainly in the CAA). Using this mask along with the model-specific land mask reduces climatological SCE in the models but has minimal impact on their trends (not shown). Furthermore, the study area for this analysis is spatially restricted to the Northern Hemisphere extratropics $\left(>30^{\circ} \mathrm{N}\right)$, with Greenland excluded, and temporally restricted to March-June (MAMJ).

SCE is calculated from model output by multiplying grid cell snow cover fraction (\%) by the area of each grid cell $\left(\mathrm{m}^{2}\right)$ and then taking the hemispheric sum for each month. Similarly, snow water mass (SWM) is computed by multiplying grid cell level snow water equivalent (SWE) by the area of each grid cell and summing over the NH. This is applied to SWE data from the CanESM-LE to allow for an illustration of the influence that changes in winter precipitation have on SCE trends. The premelt SWM is a useful measure of snowfall totals over the winter months, particularly across the Arctic, because wind-driven snow processes are not represented in current models (Turner et al. 2006; Lawrence et al. 2012). We find that 1981-2010 winter (October-March) snowfall trends are strongly correlated with March SWM trends within CanESM-LE ( $r=0.92$; not shown). Along 
with measures of correlation, we also use the coefficient of determination $R^{2}$ to recognize the contribution from precipitation and temperature to SCE variability.

Time series of SCE and SWM data are used to calculate climatologies and linear trends. We calculate these values for each of the four 30-yr climatological time frames during the study period: historical (1981-2010), near-future (2011-40), midcentury (2041-70), and longterm (2071-2100). In some cases, a twenty-first-century trend (2011-2100) is used to simplify the discussion of results. Since the historical CMIP5 data end in 2005, we use RCP8.5 data to complete the 1981-2010 period so that a comparison with recent observations can be made [similar to Derksen and Brown (2012)]. SCE trends are computed as both absolute area $\left(10^{6} \mathrm{~km}^{2} \mathrm{decade}^{-1}\right)$ and percent changes $\left(\%\right.$ decade $\left.^{-1}\right)$. Absolute area calculations are useful in the context of comparing different months, whereas percent changes may be more suitable for interensemble comparisons because they account for potential differences in snow cover climatology. Throughout, all trend values reported are accompanied by one standard deviation $(1 \sigma)$ to represent uncertainty. Note that trends are calculated at each model's native resolution, and regridding to $1^{\circ} \times 1^{\circ}$ grid is only used for spatial mapping of the snow cover from the CMIP5 models. Last, the term "bias" will be used solely for comparing models in relation to observation-based estimates.

\section{Results}

\section{a. Historical spring SCE trends}

Considering first the entire spring season for the Northern Hemisphere, SCE has decreased at a mean rate of $-0.55 \pm 0.21 \times 10^{6} \mathrm{~km}^{2} \mathrm{decade}^{-1}$ from 1981 to 2010, according to the seven observation-based estimates evaluated here (Table 2). Dividing this rate by the climatological spring SCE produces a percent change of $-3.3 \%$ decade $^{-1}$. The strongest trend in terms of absolute area occurs in March (mean: $-0.66 \pm 0.26 \times$ $\left.10^{6} \mathrm{~km}^{2} \mathrm{decade}^{-1}\right)$ and the weakest in June $(-0.41 \pm$ $0.30 \times 10^{6} \mathrm{~km}^{2} \mathrm{decade}^{-1}$ ) (Fig. 1). However, direct measures of trend magnitude do not account for the much greater total snow area in March $\left(32.6 \pm 2.5 \times 10^{6} \mathrm{~km}^{2}\right)$ than June $\left(2.6 \pm 1.9 \times 10^{6} \mathrm{~km}^{2}\right.$; not shown $)$. When viewed as a percent change relative to the monthly climatology, March SCE is decreasing at a rate of $-2.0 \% \pm 0.8 \%$ decade $^{-1}$, whereas the rate of June SCE loss is $-16 \% \pm$ $11 \%$ decade $^{-1}$ (not shown). Both early spring and June trends found here are weaker than those previously reported that were based only on the NOAA CDR; BrutelVuilmet et al. (2013) reported trends of $-3.4 \%$ decade $^{-1}$

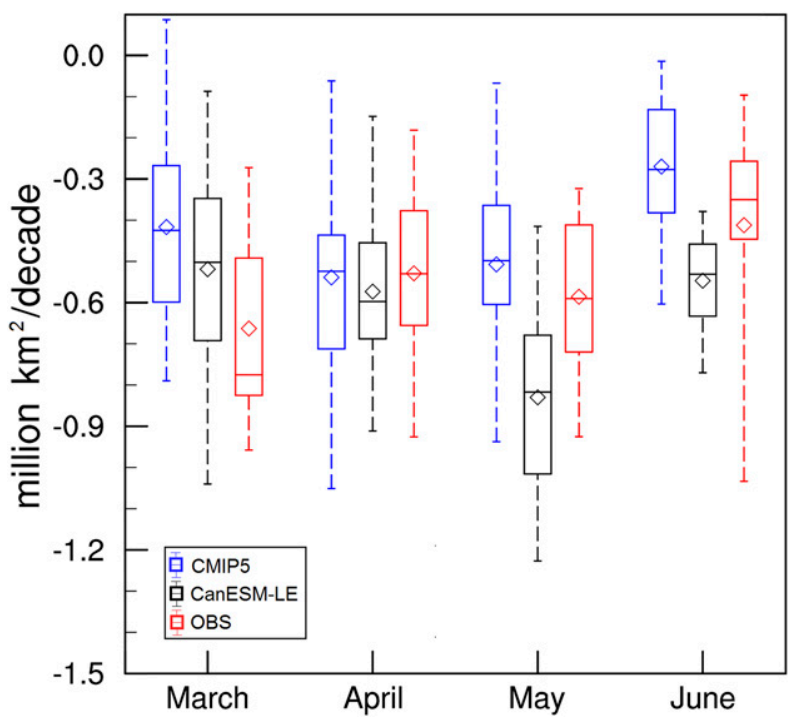

FIG. 1. Historical (1981-2010) Northern Hemisphere extratropical snow cover extent trends among three ensembles: CMIP5, CanESM-LE, and observation-based (OBS). For each box the enclosed region shows the 25 th-75th percentile range, the horizontal line shows the median, and the diamond shows the ensemble mean. The dashed whiskers indicate the minimum and maximum. The CMIP5 box uses the mean for each model (averaged over all available realizations).

for March-April over the 1979-2005 period, and Derksen and Brown (2012) reported trends of $-18 \%$ decade $^{-1}$ in June over the 1979-2011 period.

These reported differences result because there is a substantial spread among the observation-based estimates of SCE trends, and of the seven products evaluated here the NOAA CDR trends are the largest in magnitude (Table 2). Mudryk et al. (2015) have recently shown an analogously large spread in SWM trends from various snow analysis products. Such spread likely occurs as a result of differences in methodology and the type of data used to construct each dataset (e.g., in situ, reanalysis, satellite-derived). Three of the four reanalysis products (GLDAS-2, ERA-I-Land, and MERRA) exhibit the weakest spring SCE trends over recent decades, with GLDAS-2 losing the least SCE in each spring month. On the other hand, two of the three products that utilize either satellite-derived or in situ information (NOAA CDR and Brown dataset) exhibit the strongest trends in spring SCE over the recent past.

Simulated spring trends from the CMIP5 models are approximately $22 \%$ weaker than observed on average [multimodel ensemble mean $(\mathrm{MM}):-0.43 \pm 0.17 \times$ $10^{6} \mathrm{~km}^{2} \mathrm{decade}^{-1}$ or $\left.-2.5 \% \pm 1.0 \% \mathrm{decade}^{-1}\right]$. This is also weaker than that of the CanESM-LE (mean = $-0.62 \pm 0.18 \times 10^{6} \mathrm{~km}^{2} \mathrm{decade}^{-1}$ ), which demonstrates much greater late-spring snow loss. From a monthly 
perspective, the CMIP5 mean SCE trend is largest during April and weakest in June (Fig. 1). The agreement between CMIP5 models and observations is very good during April and May, but less so during March and June, when the models have weaker trends (MM: $-1.4 \% \pm$ $0.8 \%$ decade $^{-1}$ and $-8.4 \% \pm 5.4 \%$ decade $^{-1}$, respectively). However, March is the only month with a statistically significant difference between the observed and simulated mean trends ( $p<0.05$; using a two-sided Student's $t$ test). Furthermore, nearly all models exhibit negative SCE trends throughout the spring, except for INM-CM4.0, which has a slight increasing trend during March. The CMIP5 models range from losing very little snow in MAMJ at $13 \%$ of the observed baseline $\left(-0.07 \times 10^{6} \mathrm{~km}^{2} \mathrm{decade}^{-1}\right)$ to $142 \%$ of observed $\left(-0.78 \times 10^{6} \mathrm{~km}^{2} \mathrm{decade}^{-1}\right)($ Table 1$)$. As a demonstration that single model contributions to the CMIP5 archive may underestimate internal variability, CanESM2 is the model with the greatest spring snow loss of any CMIP5 model from 1981 to 2010, yet we find that CanESM-LE (the large ensemble produced using the same model) is much closer to the CMIP5 average (Fig. 2).

The variability in 30-yr trends from the CMIP5 ensemble is equally large for March, April, and May (standard deviation $\sigma=0.24 \times 10^{6} \mathrm{~km}^{2} \mathrm{decade}^{-1}$ ) and slightly lower in June $\left(\sigma=0.17 \times 10^{6} \mathrm{~km}^{2} \mathrm{decade}^{-1}\right)$. However, when we examine $10-y r$ trends the spread widens dramatically for all spring months. For example, in May the simulated range (maximum-minimum) for decadal trends is more than 7 times that for 30 -yr trends (from -3.7 to $2.7 \times 10^{6} \mathrm{~km}^{2}$ decade $^{-1}$; see Fig. S1 in the supplemental material). This highlights the larger contribution to the SCE trends from internal variability, compared to the forced response to GHG increases, over shorter time periods. This result is consistent with similar findings for temperature and precipitation trends (Hawkins and Sutton 2009, 2011). The following section will investigate possible factors contributing to the large intermodel spread within historical simulations from the current generation of climate models.

\section{b. Sources of model uncertainty: Historical trends}

\section{1) SENSITIVITY OF SCE TO WARMING TRENDS}

First we evaluate how differences in warming could be affecting the simulated intermodel spread in SCE trends. Although a very important contributor $\left(R^{2}=0.74\right)$, differences in simulated warming do not explain all of the intermodel spread in spring SCE trends for the 1981-2010 period. We use mean extratropical land warming rather than local warming because unnaturally high sensitivities can occur for some models in areas where the warming trend is close to zero. The observed spring $\mathrm{NH}$

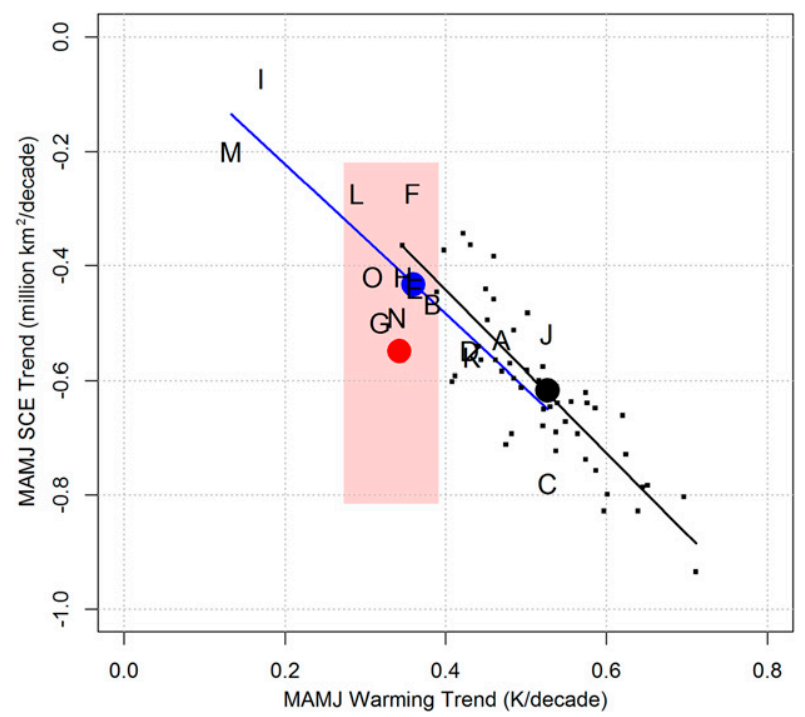

FIG. 2. Relationship between spring SCE trends and NH extratropical land warming for the CMIP5 models during the historical period (1981-2010). Each model is represented by a letter, corresponding to the information in Table 1 . Filled circles represent the CMIP5 (blue), CanESM-LE (black), and the observation-based mean (red). Each member of the CanESM-LE is shown as a small black square. The shaded red rectangle illustrates the range of observation-based trends. Models that fall to the bottom-left portion of the plot are most sensitive to warming.

extratropical land warming trend over the 1981-2010 period is $0.34 \pm 0.04 \mathrm{Kdecade}^{-1}$. On average, the CMIP5 models accurately capture spring warming over recent decades, with an ensemble mean of $0.36 \pm 0.11 \mathrm{~K} \mathrm{decade}^{-1}$ (Fig. 2). In contrast, the CanESM-LE has a greater mean warming trend $\left(0.52 \pm 0.08 \mathrm{~K} \mathrm{decade}^{-1}\right)$, which overlaps with the CMIP5 warming trend but falls outside the uncertainty range of the observed warming trend. The mean trend seen in the CanESM-LE ensemble reflects the majority of CMIP5 models (10 out of 15) that simulate recent (1981-2010) spring warming that is greater than or equal to the warming found in observations.

Despite realistically reproducing observed temperature trends, only two models produce more snow loss than the observation-based estimates. This suggests that snow in some models tends to be less sensitive to temperature variations than in observations. To quantify this property of the models, we compute a snowmelt sensitivity $\lambda_{\text {smelt }}=\langle\Delta \mathrm{SCE}\rangle /\left\langle\Delta T_{s}\right\rangle$, which measures how much SCE is reduced per degree of warming, averaged over the NH land area (averaging is denoted by the angle brackets). Observed spring $\lambda_{\text {smelt }}$ during the spring months (MAMJ mean) is $-1.62 \pm 0.61 \times 10^{6} \mathrm{~km}^{2} \mathrm{~K}^{-1}$, with the large uncertainty driven mainly by disagreement among the observed SCE trends (illustrated by the shaded rectangle in Fig. 2), which creates a large spread 
among the 35 possible combinations of observed temperature (5 products) and SCE ( 7 products). This exceeds the estimate of $\lambda_{\text {smelt }}$ that is computed for both the CanESM-LE $\left(-1.18 \pm 0.15 \times 10^{6} \mathrm{~km}^{2} \mathrm{~K}^{-1}\right)$, and the CMIP5 ensemble $\left(\mathrm{MM}=-1.19 \pm 0.31 \times 10^{6} \mathrm{~km}^{2} \mathrm{~K}^{-1}\right)$. The $68 \%$ confidence interval for the CMIP5 estimate of $\lambda_{\text {smelt }}$ overlaps that from observations, indicating that the two estimates of mean snowmelt sensitivity are not significantly different. However, similar to Brutel-Vuilmet et al. (2013), we find that the weaker-than-observed SCE trends from the CMIP5 ensemble are likely due in part to a weaker-than-observed snow response to warming.

\section{2) Climatological MeAn SNOw COver}

A secondary cause of the weaker-than-observed SCE trends in CMIP5 is biases in the simulated climatological (1981-2010 mean) snow cover ( $\overline{\mathrm{SCE}}$ ) for a given month. The ability to accurately represent present-day snow cover is important for simulated SCE trends because of a positive correlation between snow extent and SAF strength (Levis et al. 2007). This relationship indicates that models with greater SCE produce stronger SAF for a given rise in temperature, because larger SCE implies a greater potential area over which albedo can be reduced from its snow-covered to its snow-free value. In the CMIP5 multimodel mean, nearly all land poleward of $45^{\circ} \mathrm{N}$ is at least $50 \%$ snow covered in March (Fig. 3a; MM $\overline{\mathrm{SCE}}$ of $\sim 30.5 \pm 3.5 \times 10^{6} \mathrm{~km}^{2}$ ). However, there is a significant spread in March $\overline{\mathrm{SCE}}$ within the CMIP5 ensemble: the model with the highest $\overline{\text { SCE }}$ has $18 \%$ more snow-covered area than the mean (red line in Fig. 3a), whereas the model with the lowest $\overline{\text { SCE }}$ has $28 \%$ less snow cover than the mean (green line in Fig. 3a). Much of the disparity between these models is found across western North America, western Eurasia, and the Tibetan Plateau (similarly for April; Fig. 3b). Comparatively, the observation-based estimates show $\overline{\mathrm{SCE}}$ ranging from 30 to $36 \times 10^{6} \mathrm{~km}^{2}$ in March, with a mean of approximately $32 \times 10^{6} \mathrm{~km}^{2}$. Disparity between the minimum and maximum observation-based snow cover products is greatest over eastern Eurasia and western North America (Fig. 3a). Of note is the good agreement over western Eurasia, where both of the extreme observation-based estimates exceed or closely resemble the maximum model extent. This implies that the CMIP5 models may be systematically underestimating early spring snow cover in this region.

Late spring (May-June) snow cover resides primarily across the Arctic $\left(>60^{\circ} \mathrm{N}\right)$, with much of the high latitudes still more than $50 \%$ snow covered during May (Fig. 3c). On average, the CMIP5 models simulate May $\overline{\mathrm{SCE}}$ of $11.8 \pm 3.9 \times 10^{6} \mathrm{~km}^{2}$, while the observationbased products range from 6.9 to $14.7 \times 10^{6} \mathrm{~km}^{2}$, with a mean of $10.6 \pm 2.6 \times 10^{6} \mathrm{~km}^{2}$. In June any remaining snow cover is restricted to Siberia, Arctic Canada, and Alaska and is characterized by local snow cover fractions lower than $50 \%$ (CMIP5 mean $\overline{\mathrm{SCE}}$ is $3.2 \pm 2.0 \times$ $10^{6} \mathrm{~km}^{2}$; Fig. 3d). Similar to the models, the observationbased estimates have a mean of $2.6 \pm 1.9 \times 10^{6} \mathrm{~km}^{2}$, and a large spread spanning from 0.5 (GLDAS-2) to $5.9 \times$ $10^{6} \mathrm{~km}^{2}$ (NOAA CDR). Note that differences between models in their $\overline{\mathrm{SCE}}$ values is likely the result of model uncertainty, rather than internal variability, as demonstrated by a very small range within the CanESM-LE $\left(<1 \times 10^{6} \mathrm{~km}^{2}\right.$ for all spring months; not shown).

Biases in June $\overline{\text { SCE }}$ have the most significant impact on SCE trends of any month: those models with minimal SCE in June tend to show very weak SCE trends because in the future there is so little snow left to melt. The models with low June SCE (e.g., BCC_CSM1.1, CSIRO Mk3.6, INM-CM4.0, and MPI-ESM-LR; see Fig. S2 in the supplemental material) exhibit a mean SCE trend of only $-0.06 \times 10^{6} \mathrm{~km}^{2}$ decade $^{-1}$ (not shown), a factor of 6 weaker than the other CMIP5 models $(-0.35 \times$ $10^{6} \mathrm{~km}^{2}$ decade ${ }^{-1}$; not shown). These same models with low June $\overline{\mathrm{SCE}}$ have previously been shown to have mean late spring near-surface air temperatures that are substantially warmer than the other CMIP5 models (Thackeray et al. 2015). Therefore, biases in SCE can affect the SCE trend in seasons when SCE becomes limited (e.g., late spring).

There is a slightly weaker correlation $(r=0.43)$ between trends in 1981-2010 March SWM (used as a proxy for variability in winter snowfall) and MAMJ SCE trends within the CMIP5 ensemble (not shown). A moderately strong correlation also exists between March SWM trends and $\lambda_{\text {smelt }}(r=0.70)$. However, because SWM does not have the same subseasonal importance as $\overline{\mathrm{SCE}}$ (there is a weak correlation with SCE trends for all months other than March) it is not investigated further. Furthermore, although there are many other potential sources of model uncertainty in simulated SCE (e.g., model resolution, land surface scheme complexity, and climatological temperature biases), we do not find any clear linkages between these parameters and spring SCE trends, so they are not discussed further.

\section{c. Projected trends in spring SCE}

To evaluate projections of future spring SCE, we use two model ensembles: the multimodel CMIP5 ensemble and the CanESM-LE. As previously noted, the latter only contains (land-atmosphere-ocean induced) spread due to internal variability, so it provides a useful benchmark to compare with the estimate of intermodel spread from CMIP5. It should be noted that CanESM-LE provides one model's estimate of internal variability, which 

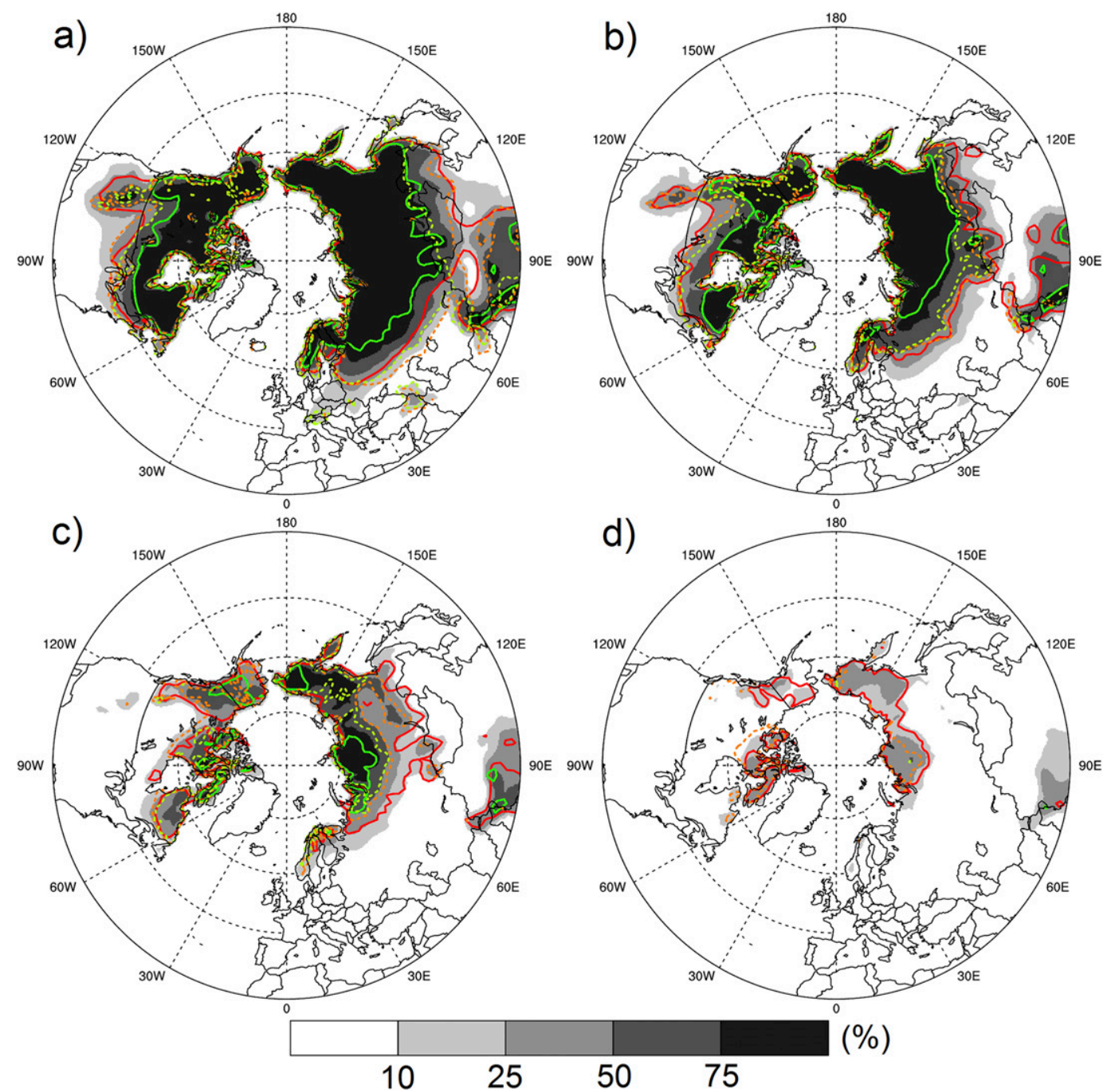

FIG. 3. Spatial distribution of monthly mean historical (1981-2010) snow cover fraction (\%) from the CMIP5 ensemble mean for (a) March, (b) April, (c) May, and (d) June. Solid contours show the boundary of the region with $>50 \%$ SCF for the model with minimum (green line) and maximum (red line) SCE during each month. Dotted contours show the minimum (yellow) and maximum (orange) observation-based estimates of the region with $>50 \%$ SCF. The observational minimum does not appear in June because SCF is below $50 \%$ everywhere.

could vary for other CMIP5 models (e.g., Kay et al. 2015). First, we discuss the median projected change for the spring as a whole, followed by early (March-April) and late spring (May-June). On average, the CMIP5 models project that spring SCE trends will strengthen during the twenty-first century relative to the recent past. The mean rate of spring snow loss over the twenty-first century (20112100 trend) is approximately $-3.7 \% \pm 1.1 \%$ decade $^{-1}$, $33 \%$ greater than in the period 1981-2010 (Fig. S3 in the supplemental material). Similarly, the CanESM-LE exhibits a strengthening of $41 \%$ (more negative) compared to its 1981-2010 trend. However, CanESM2 exhibits the strongest 1981-2010 trend of the CMIP5 models (Table 1) so the median rate of twenty-first-century spring snow loss from CanESM-LE is also larger $\left(-4.3 \%\right.$ decade $\left.^{-1}\right)$.

The CMIP5 models project that early spring (MarchApril) SCE trends will strengthen in the twenty-first century relative to the recent past (Figs. 4a,b). The mean SCE responses over the twenty-first century (2011-2100 trend) from CMIP5 $\left(-0.80 \pm 0.23 \times 10^{6} \mathrm{~km}^{2} \mathrm{decade}^{-1}\right)$ and CanESM-LE $\left(-1.02 \pm 0.22 \times 10^{6} \mathrm{~km}^{2} \mathrm{decade}^{-1}\right)$ are more than $65 \%$ stronger than their respective simulated rates for the period of 1981-2010. This is consistent with greater simulated rates of warming during the twenty-first century (not shown). Since these two ensembles have different mean $\overline{\mathrm{SCE}}$ (Table 3), we also calculate the ensemble mean percentage of snow loss 

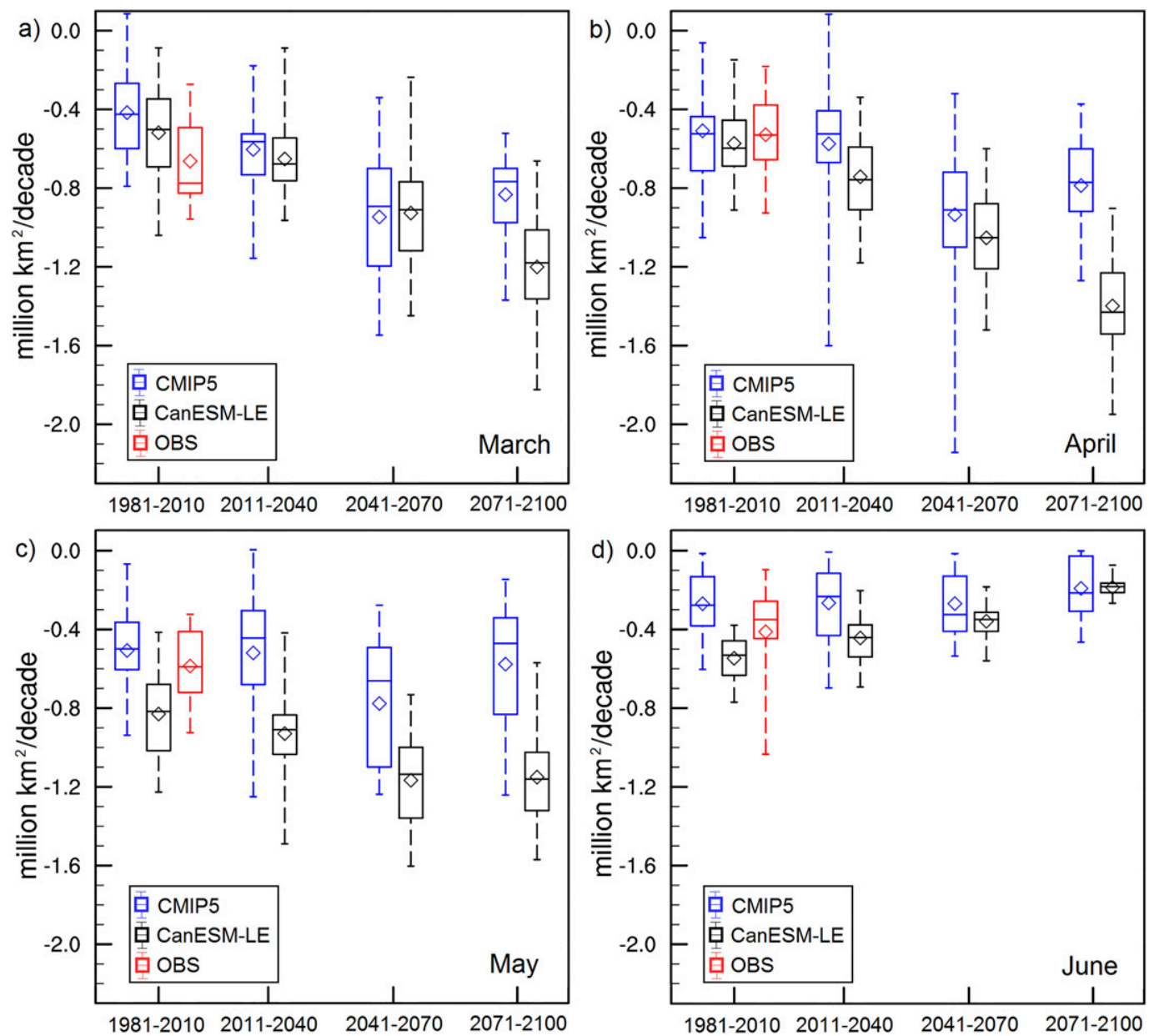

FIG. 4. Northern Hemisphere (a) March, (b) April, (c) May, and (d) June SCE trends over the twenty-first century under the RCP8.5 emissions scenario for the CMIP5, CanESM-LE, and observation-based (OBS) ensembles. As in Fig. 1, each box shows the 25th-75th percentile range, the horizontal line shows the ensemble median, and the diamond shows the ensemble mean. The dashed whiskers indicate the ensemble minimum and maximum. Trends are shown in millions of square kilometers per decade and split into four 30-yr climatological periods (1981-2010, 2011-40, 2041-70, and 2071-2100).

over the twenty-first century to account for differences in the amount of snow cover available for melt: the CMIP5 models lose $-3.0 \% \pm 0.9 \%$ decade $^{-1}$, while CanESM-LE loses $3.3 \% \pm 0.7 \%$ decade $^{-1}$.

Within the CMIP5 ensemble, mean twenty-first-century May SCE loss (2011-2100 trend) is projected to strengthen slightly (by $\sim 25 \%$ ) compared to the 1981-2010 trend. Trends in May also exhibit the greatest discrepancy between CMIP5 $\left(-5.5 \% \pm 2.0 \%\right.$ decade $\left.^{-1}\right)$ and CanESM-LE $\left(-6.5 \% \pm 1.3 \%\right.$ decade $\left.^{-1}\right)$ (Fig. $4 c$ ). Unlike the other months, June SCE trends are projected to weaken over the course of the twenty-first century (Fig. 4d). A gradual weakening within CanESM-LE is tied to a significant reduction in the amount of snow area remaining for melt (mean SCE $<0.5 \times 10^{6} \mathrm{~km}^{2}$ by $2071-$ 2100). This same reasoning explains why the simulated
June trends (even under the most aggressive GHG forcing scenario) of $-8.1 \% \pm 4.9 \%$ decade $^{-1}$ from CMIP5 and $-8.7 \% \pm 1.9 \%$ decade $^{-1}$ from CanESM-LE are weaker than observed in recent decades $\left(-16 \%\right.$ decade $\left.^{-1}\right)$. In summary, rates of projected snow cover loss are expected to increase for all spring months, with the exception of June, where a relatively small SCE remains in the latter half of the twenty-first century.

Last, we consider the intermodel spread of land surface warming trends as a possible source of uncertainty for projected spring SCE trends within the CMIP5 ensemble. We estimate the uncertainty in the CMIP5 projections using the multimodel standard deviation (Hawkins and Sutton 2011), and we average $\sigma$ over three different $30-y r$ periods (2011-40, 2041-70, and 2071-2100). This procedure yields uncertainties in SCE 
TABLE 3. Projected twenty-first-century (2011-2100) mean SCE trends (area and percent) along with 1981-2010 mean climatological SCE for each spring month. Percent loss is calculated by dividing the absolute area trend by mean SCE.

\begin{tabular}{|c|c|c|c|c|c|c|}
\hline & \multicolumn{2}{|c|}{$\begin{array}{l}\text { Projected absolute area trend } \\
\qquad\left(10^{6} \mathrm{~km}^{2} \text { decade }^{-1}\right)\end{array}$} & \multicolumn{2}{|c|}{$\begin{array}{l}\text { Projected percent loss trend } \\
\qquad\left(\% \text { decade }^{-1}\right)\end{array}$} & \multicolumn{2}{|c|}{$1981-2010$ mean SCE $\left(10^{6} \mathrm{~km}^{2}\right)$} \\
\hline & CMIP5 & CanESM-LE & CMIP5 & CanESM-LE & CMIP5 & CanESM-LE \\
\hline March & $-0.80 \pm 0.23$ & $-0.96 \pm 0.22$ & $-2.6 \pm 0.7$ & $-2.8 \pm 0.7$ & $30.5 \pm 3.6$ & $33.9 \pm 0.2$ \\
\hline April & $-0.80 \pm 0.25$ & $-1.08 \pm 0.21$ & $-3.6 \pm 1.1$ & $-3.9 \pm 0.8$ & $22.5 \pm 4.0$ & $27.4 \pm 0.2$ \\
\hline May & $-0.64 \pm 0.24$ & $-1.10 \pm 0.22$ & $-5.5 \pm 2.0$ & $-6.5 \pm 1.3$ & $11.8 \pm 3.9$ & $16.9 \pm 0.2$ \\
\hline June & $-0.26 \pm 0.17$ & $-0.35 \pm 0.07$ & $-8.1 \pm 4.9$ & $-8.7 \pm 1.9$ & $3.2 \pm 2.0$ & $4.0 \pm 0.1$ \\
\hline
\end{tabular}

trends for March $\left(\sigma=0.28 \times 10^{6} \mathrm{~km}^{2} \mathrm{decade}^{-1}\right)$, April $\left(\sigma=0.36 \times 10^{6} \mathrm{~km}^{2} \mathrm{decade}^{-1}\right)$, May $\left(\sigma=0.34 \times 10^{6} \mathrm{~km}^{2}\right.$ decade $\left.^{-1}\right)$, and June $\left(\sigma=0.18 \times 10^{6} \mathrm{~km}^{2}\right.$ decade $\left.^{-1}\right)$. Taking the example of the relatively large uncertainty in April, we find a wide range of projected SCE trends for the 2011-40 period, from a small gain in one model to a loss of $-1.6 \times 10^{6} \mathrm{~km}^{2} \mathrm{decade}^{-1}$ in another model (Fig. S4 in the supplemental material). In this case, the model with the strongest (weakest) SCE loss also warms the most (least) over this period. Warming trends explain much of the intermodel spread in early spring SCE trends $\left(R^{2}=0.79\right.$; Fig. 5), whereas June SCE trends are heavily influenced by biases in $\overline{\mathrm{SCE}}\left(R^{2}=0.93\right.$; Fig. 5$)$. For the spring as a whole, variability in twenty-first-century $\mathrm{NH}$ land warming explains approximately $80 \%$ of the intermodel spread in SCE trends. Therefore, reducing variability in simulated future warming should in turn reduce uncertainty in SCE trends (further discussed in section 4).

\section{d. The contribution of internal variability to projected trends in SCE}

Many of the CMIP5 models that project extremely strong or weak spring SCE trends contributed only a single realization in the CMIP5 archive, while considerably better agreement in projected SCE trends exists among the set of four models that contributed $n \geq 5$ realizations (particularly in early spring when warming trends dominate; not shown). This motivates an important question as to the role of internal variability in SCE trends; however, the majority of CMIP5 models completed fewer than five realizations, which is likely insufficient for estimating internal variability (Kay et al. 2015).

The 50-realization CanESM-LE exhibits a smaller spread in MAMJ SCE trends throughout the twentyfirst century than the CMIP5 ensemble ( $\sigma=0.18$ and $0.29 \times 10^{6} \mathrm{~km}^{2}$ decade $^{-1}$, respectively, averaged over three epochs 2011-40, 2041-70, and 2071-2100). Internal variability, as indicated by the shading for CanESM-LE in Fig. 6, is likely a very important contributor to the intermodel spread in the near term (2011-40), but the fraction of total variance within the CMIP5 ensemble attributable to internal variability decreases on longer time scales as a relatively larger fraction is explained by model uncertainty (Fig. 6). This same finding has also been shown for precipitation and temperature trends, where internal variability has a greater influence in the near future than at the end of the century (Hawkins and Sutton 2009, 2011).

Last, to demonstrate the interplay between internal variability and model uncertainty, we can compare the results from CanESM-LE with the intraensemble spread for all CMIP5 models with $n \geq 5$ realizations available for the RCP8.5 experiment (CanESM2, CCSM4, CNRM-CM5, and CSIRO Mk3.6.0). This subset of models, which we assume provides an improved estimate of model uncertainty isolated from internal variability, contains substantial variation, both in the intermodel SCE trends $\left(n=4, \sigma=0.22 \times 10^{6} \mathrm{~km}^{2}\right.$ decade $\left.^{-1}\right)$ and the interrealization variability $(n=26$, minimum and maximum $\sigma$ are 0.12 and $0.23 \times 10^{6} \mathrm{~km}^{2}$ decade $^{-1}$ ). The interrealization spread of trends for each model is thus of similar magnitude to the intermodel spread, making it plausible that a significant fraction of the intermodel spread is caused by internal variability. We find considerable similarities between this analysis and the work on trends in

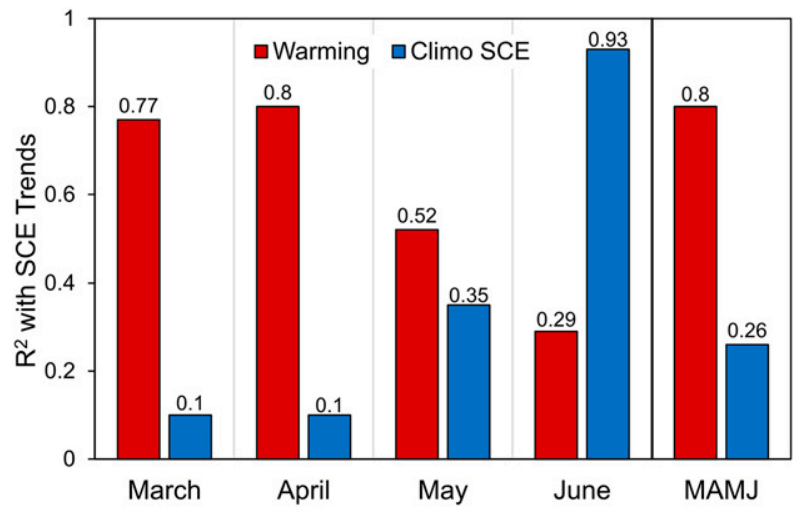

FIG. 5. Bar plot showing the $R^{2}$ for twenty-first-century SCE trends (2011-2100) from CMIP5 predicted based on projected NH extratropical land warming trends (red) and climatological SCE (blue) as predictors for March, April, May, and June. MAMJ values are calculated from the average seasonal trends in SCE and temperature rather than as an average of $R^{2}$ values. 

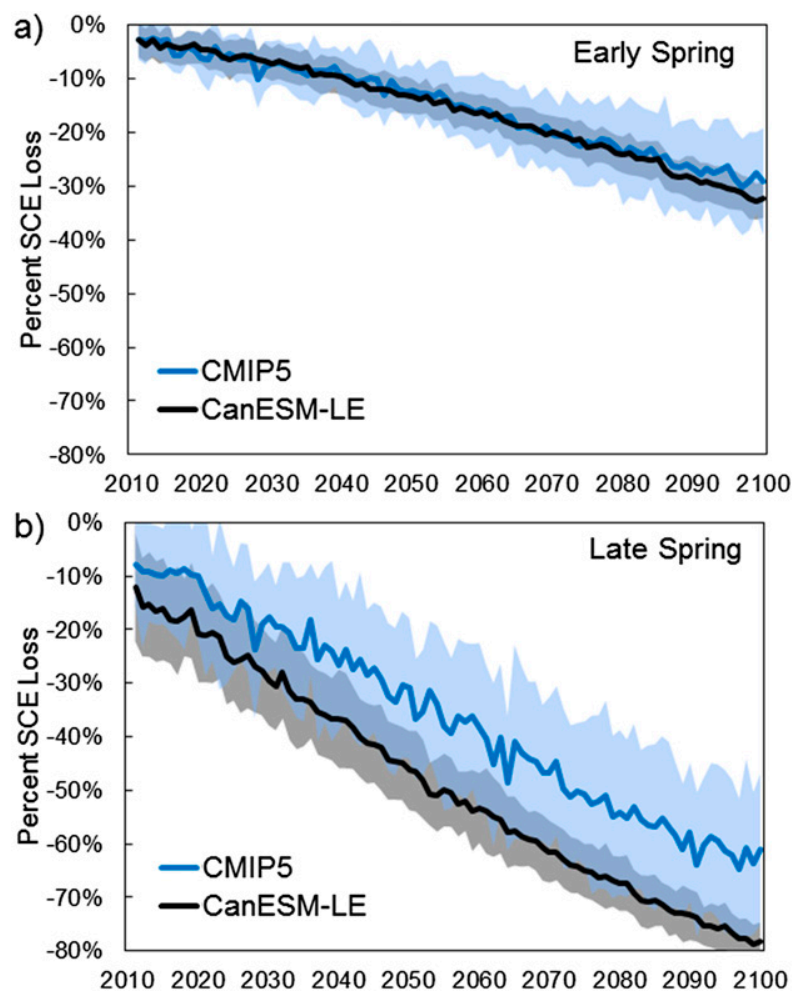

FIG. 6. Percentage of climatological Northern Hemisphere SCE (1981-2010 mean) lost over the twenty-first century in CMIP5 and CanESM-LE for (a) early spring and (b) late spring. Ensemble mean shown with plus and minus one standard deviation shading. Note that the decreasing CanESM-LE variability in (b) is caused by June SCE falling closer to zero.

September Arctic sea ice extent (SIE) by Swart et al. (2015). For example, there is a remarkable similarity in the contributions from internal variability and model uncertainty to projected trends of SIE and SCE (not shown). The conclusion for near-term projections is that the large contribution from internal variability presents a challenge to determining the physical cause of 30-yr SCE trends.

\section{CASE STUDY: MAY SCE TRENDS IN CANESM-LE}

In the CanESM-LE, near-future (2011-40) springtime (MAMJ) SCE trends range from -0.26 to $-1.08 \times$ $10^{6} \mathrm{~km}^{2}$ decade $^{-1}$, with the largest monthly spread occurring in May (from -0.42 to $-1.49 \times 10^{6} \mathrm{~km}^{2}$ decade $^{-1}$ ). For May, this represents a more than doubling of the range exhibited by the five CanESM2 runs contributed to CMIP5 (from -0.69 to $-1.11 \times 10^{6} \mathrm{~km}^{2} \mathrm{decade}^{-1}$ ). We will therefore use May as a case study for better understanding the primary physical factors contributing to the spread.

First, we examine the contribution from variations in trends of near-surface air temperature. Only a relatively small fraction $(17 \%)$ of the interrealization variability in
TABLE 4. Correlation between May SCE trends (2011-40) and global annual mean temperature, Northern Hemisphere extratropical land temperature, Arctic land temperature, and Northern Hemisphere March SWM within the CanESM large ensemble.

\begin{tabular}{lccc}
\hline \multicolumn{1}{c}{ Variable } & Time period & Correlation & $R^{2}$ \\
\hline Global annual temperature & $2011-40$ & -0.41 & 0.17 \\
NH May temperature & $2011-40$ & -0.67 & 0.45 \\
Arctic May temperature & $2011-40$ & -0.69 & 0.47 \\
NH March SWM & $2011-40$ & 0.44 & 0.19 \\
\hline
\end{tabular}

CanESM-LE projected near-future May SCE trends is explained by annual mean global surface warming (land plus ocean), with $r=-0.41$ (Table 4 ) and the negative sign implying that enhanced global warming is associated with greater snow loss. However, nearly half of the interrealization variability $(45 \%)$ is explained when we restrict the analysis to include only contemporaneous (e.g., May) and local (e.g., NH extratropical land averaged) temperatures (Fig. 7a; $r=-0.67$ ). The majority of May snow cover resides across the Arctic (Fig. 3c), so one would expect an even stronger correlation with temperature there if local warming were the only contributor to differences in SCE trends. Yet, when we restrict the temperatures to the $\operatorname{Arctic}\left(>60^{\circ} \mathrm{N}\right)$ region, the relationship becomes only slightly stronger $(r=-0.69)$. This demonstrates that differences in simulated warming cannot fully account for variability within CanESM-LE SCE trends, and so next we examine the roles for changes in precipitation and atmospheric circulation.

Whereas in CMIP5 we find that June SCE trends are highly correlated with the intermodel spread in June climatological SCE (Fig. 5), the spread in climatological SCE in CanESM-LE is minimal $\left(<1 \times 10^{6} \mathrm{~km}^{2}\right)$ for all spring months and there is no correlation with SCE trends (not shown). However, we do find a relationship in CanESM-LE between spring SCE trends and snow accumulation during the previous winter. We use March SWM as a proxy for simulated snowfall totals over the winter months, and find a weak positive correlation $(r=0.44$ for 2011-40; see Table 4; note that the $R^{2}$ values for other climatological periods are shown in Fig. 7b) between twenty-first-century trends in SWM and May SCE. To illustrate the importance of SWM for interrealization differences in SCE trends, in Fig. 7 we compare May land warming, May SCE loss and March SWM loss over the NH extratropics for the period 2011-40. Across the 50 realizations May land warming varies from 0.35 to $0.78 \mathrm{~K} \mathrm{decade}^{-1}$, and the realization that warms the most (run 40) also produces the greatest SCE loss (Fig. 7a). However, the realization with the weakest SCE loss (run 1) is not the realization with the least warming (run 49). The reason is that a weaker-than-average 

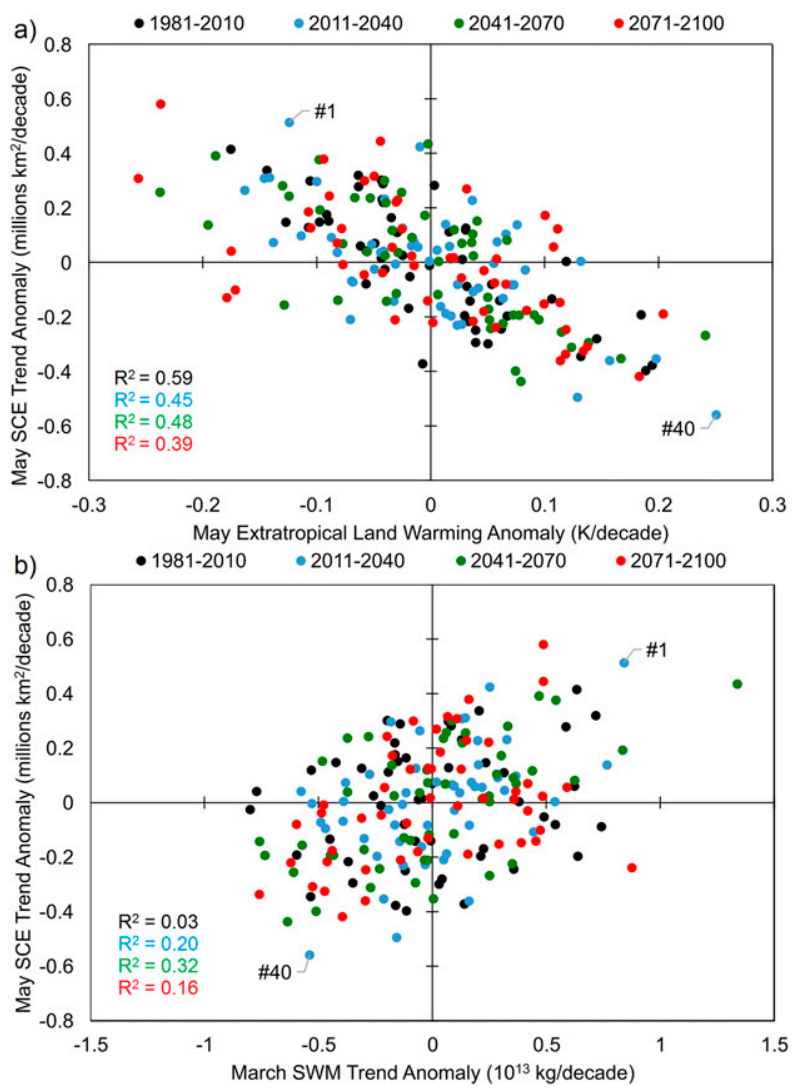

FIG. 7. Relationship between May SCE trend anomalies within CanESM-LE and (a) May warming anomalies over NH extratropical land and (b) March SWM anomalies over NH extratropical land. Each realization is represented by four points, one for each of the climatological periods (color coded). Trend anomalies are calculated by removing the ensemble mean (forced component). The $R^{2}$ value for each time period is shown in the bottom-left corner (color coded).

decreasing trend in March SWM in run 1 contributes to a weaker-than-average SCE trend (Fig. 7b). Positive SWM anomalies extend snow cover duration because greater melt energy is required to remove deeper snow.

Last, we explore the role of local temperature and atmospheric circulation changes in explaining the interrealization spread in CanESM-LE SCE trends. We compute local correlations between near-future May SCF trends and contemporaneous temperature and sea level pressure (SLP) changes. Trends in temperature and snow cover have a very strong negative association over most $\mathrm{NH}$ areas with substantial May snow cover (Fig. 8a). For SLP, the relationship with snow cover is of hemispheric spatial scale, with moderate correlations of either sign that project onto the North Atlantic Oscillation (NAO) pattern (Barnston and Livezey 1987) (Fig. 8b). Greater Eurasian snow loss is associated with an increased meridional pressure gradient across the North Atlantic typical of a positive NAO phase, bringing enhanced warm advection into Eurasia. In contrast, contributions to changes in western North American SCE largely stem from North Pacific SLP patterns. Figure $8 \mathrm{~b}$ consequently represents a combination of several unique circulation patterns. This demonstrates that atmospheric circulation responses associated with internal variability exert an influence on near-term SCE trends over much of NH land.

\section{Discussion and conclusions}

This study uses seven observation-based estimates of snow cover, five surface temperature datasets, and two climate model ensembles to characterize the uncertainty in simulations of $\mathrm{NH}$ spring snow cover extent. We find that weaker than observed historical (1981-2010) SCE trends from the CMIP5 ensemble can be partially explained by biases in climatological spring snow extent within these models. However, biases in simulated SCE trends during recent decades are much smaller than previously shown from studies that relied on a single observation-based reference dataset (Derksen and Brown 2012; Brutel-Vuilmet et al. 2013). These studies used the NOAA CDR because of its long time series (1967-present), which we find to have the strongest spring SCE trend of the seven observation-based estimates. SCE in some models appears to lack sensitivity to warming, but the ensemble means are not significantly different.

Spring snow cover is projected to decrease by $-3.7 \% \pm 1.1 \%$ decade $^{-1}$ within the CMIP5 ensemble over the twenty-first century. This represents a strengthening of $33 \%$ relative to the rate simulated over recent decades (1981-2010). Projected snow cover loss is expected to increase for all spring months over the twentyfirst century, with the exception of June (when nearly all remaining snow has melted by the latter half of the twenty-first century). For 30-yr spring SCE trends over three time periods in the twenty-first century (2011-40, 2041-70, and 2071-2100), we find that internal variability, as estimated from the CanESM initial condition ensemble (CanESM-LE; $\sigma=0.18 \times 10^{6} \mathrm{~km}^{2} \mathrm{decade}^{-1}$ ), is substantial but smaller than the intermodel spread from CMIP5 $\left(\sigma=0.29 \times 10^{6} \mathrm{~km}^{2} \mathrm{decade}^{-1}\right)$. In contrast, the spread in SCE trends from CanESM-LE and CMIP5 are very similar for the historical period (Fig. 1). The main physical drivers of intermodel differences in projected spring SCE trends are differences in simulated warming trends $\left(R^{2}=0.80\right)$ and biases in mean SCE, with the latter more important in late spring. In theory, a reduction in the variability of projected warming should lead to a decrease in the spread of spring SCE trends. Internal variability is a major contributor 

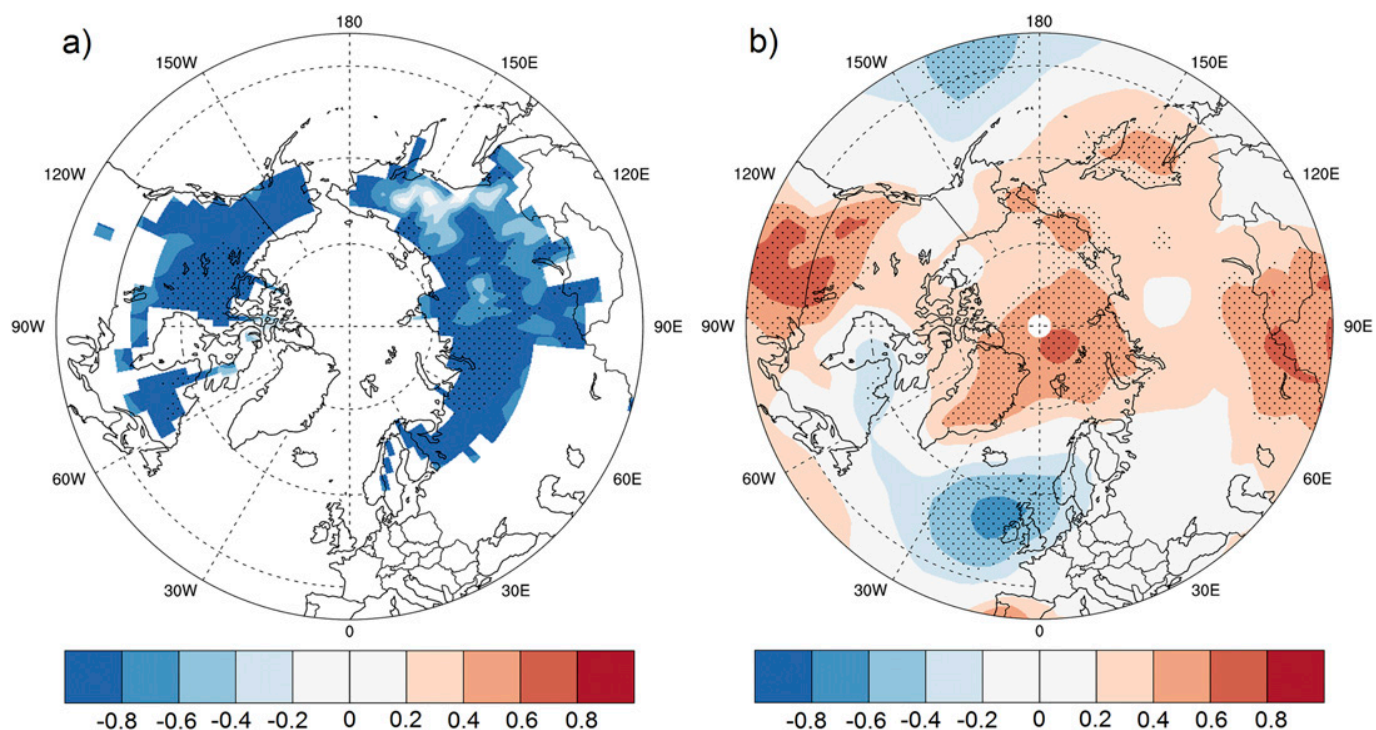

FIG. 8. (a) Local correlation between near-future (2011-40) May snow cover fraction anomalies and near-surface air temperature anomalies from the CanESM-LE, and (b) correlation between hemispheric (NH) mean May SCF anomalies and local May SLP anomalies. Stippling indicates regions of statistical significance $(p=0.05)$.

to intermodel spread (total variance) in the near-term, but the fraction of total variance attributable to internal variability decreases on longer time scales because of greater model uncertainty. We find large internal variability in near-term (2011-40) warming trends over $\mathrm{NH}$ extratropical land, which explains almost $50 \%$ of the variability in projected SCE trends, even in the presence of a strong forced trend from GHGs. Furthermore, internal variability in winter snowfall trends has a significant (but lesser) impact on SCE trends $\left(R^{2}=0.20\right)$.

There are a number of ways to potentially reduce the uncertainty in projections of NH SCE. The first involves increasing the number of realizations from each model as a part of future modeling efforts. Following the approach of Deser et al. (2012b), we calculate the minimum number of realizations $N_{\min }$ required to detect the nearfuture forced May SCF trend at the 5\% significance level,
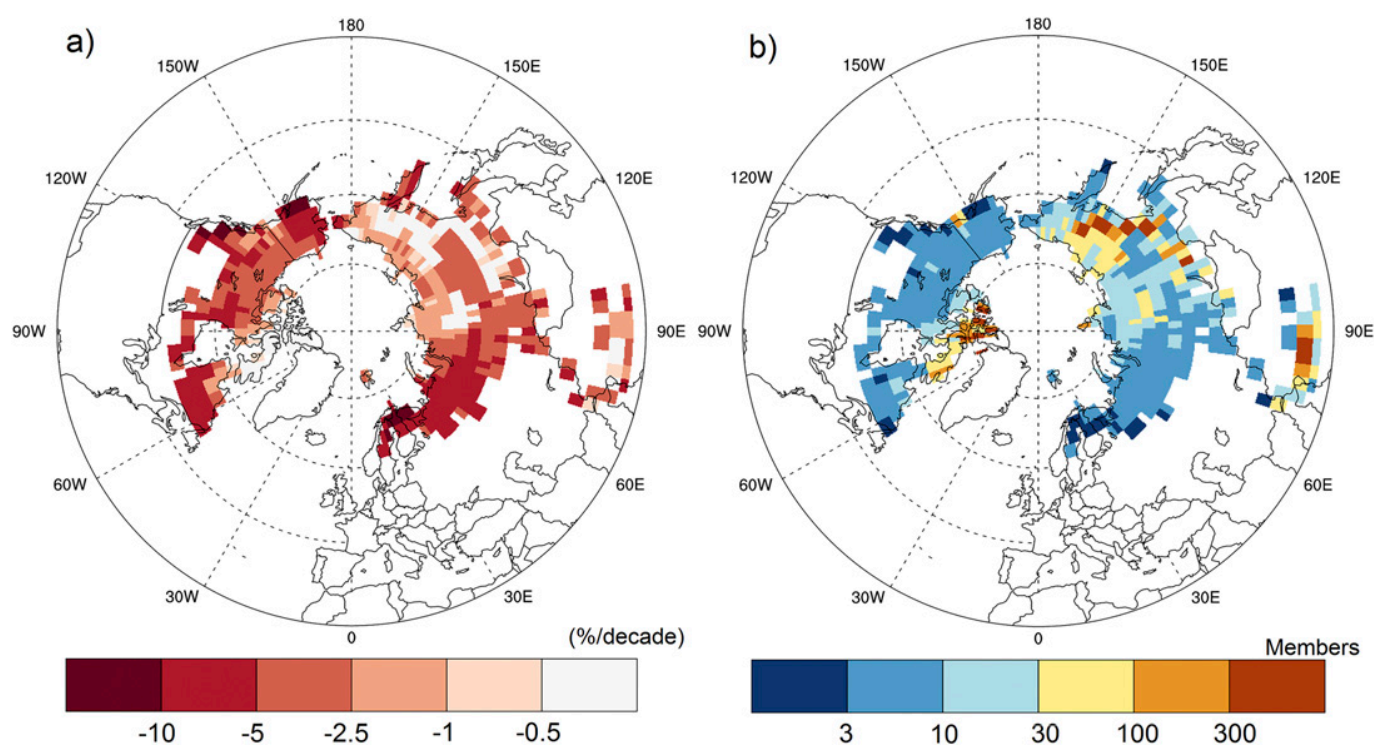

FIG. 9. (a) Near-future (2011-40) CanESM-LE ensemble mean May SCF trend. (b) The $N_{\text {min }}$ needed to detect a significant trend response in near-future May SCF. 
given by $N_{\min }=8 /(X / \sigma)^{2}$, where $X$ is the ensemble mean trend, and $\sigma$ is the standard deviation of the 50 trends. Regions with stronger snow responses generally need between 3 and 10 realizations to detect a significant trend, whereas areas with weaker responses (eastern Siberia and Canadian Arctic; Fig. 9a) require upward of 50 realizations (Fig. 9b). The implication here is not that hundreds of realizations are necessary, but that over some regions the near-term forced response is so weak that it cannot be captured. However, a majority of the models contributing to CMIP5 provided fewer than three realizations for RCP8.5.

Second, there is a very strong relationship between projected spring SCE trends and warming trends $\left(R^{2}=\right.$ 0.80). However, under RCP8.5 the CMIP5 models exhibit a rather large spread in twenty-first-century spring warming (from 0.39 to $0.95 \mathrm{~K} \mathrm{decade}^{-1}$ ). Therefore, a reduction in the uncertainty of the forced component of projected warming could lead to a decrease in the spread for spring SCE trends (the component due to internal variability is essentially random, and therefore unconstrained). Previous research has shown that $40 \%-50 \%$ of the spread in CMIP5 twenty-first-century spring warming over NH extratropical land can be explained by variability in simulated snow albedo feedback (SAF) (Qu and Hall 2014). Furthermore, Thackeray and Fletcher (2016) demonstrated that selecting only models with SAF closest to observed estimates reduces the spread in CMIP5 twenty-first-century $\mathrm{NH}$ land warming by about $40 \%$. Therefore, model development focused on alleviating process-level biases - particularly those related to SAFcould help to reduce model uncertainty in future projections of warming and snow cover.

Acknowledgments. We acknowledge funding from the Natural Sciences and Engineering Research Council of Canada's Climate Change and Atmospheric Research Initiative via the Canadian Sea Ice and Snow Evolution (CanSISE) Network (Grant 210832161). We also acknowledge Environment and Climate Change Canada's Canadian Centre for Climate Modelling and Analysis for executing and making available the CanESM2 Large Ensemble simulations used in this study. We thank Eric Brun for providing data from the Crocus snowpack model, and Ross Brown for providing the Brown dataset. We also thank three anonymous reviewers for their helpful comments.

\section{REFERENCES}

Arora, V. K., and Coauthors, 2011: Carbon emission limits required to satisfy future representative concentration pathways of greenhouse gases. Geophys. Res. Lett., 38, L05805, doi:10.1029/ 2010 GL046270.
Balsamo, G., and Coauthors, 2015: ERA-Interim/Land: A global land surface reanalysis data set. Hydrol. Earth Syst. Sci., 19, 389-407, doi:10.5194/hess-19-389-2015.

Barnett, T. P., J. C. Adam, and D. P. Lettenmaier, 2005: Potential impacts of a warming climate on water availability in snowdominated regions. Nature, 438, 303-309, doi:10.1038/ nature 04141.

Barnston, A. G., and R. E. Livezey, 1987: Classification, seasonality and persistence of low-frequency atmospheric circulation patterns. Mon. Wea. Rev., 115, 1083-1126, doi:10.1175/ 1520-0493(1987)115<1083:CSAPOL > 2.0.CO;2.

Bartlett, P. A., M. D. MacKay, and D. L. Verseghy, 2006: Modified snow algorithms in the Canadian land surface scheme: Model runs and sensitivity analysis at three boreal forest stands. Atmos.-Ocean, 44, 207-222, doi:10.3137/ao.440301.

Bekryaev, R. V., I. V. Polyakov, and V. A. Alexeev, 2010: Role of polar amplification in long-term surface air temperature variations and modern arctic warming. J. Climate, 23, 3888-3906, doi:10.1175/2010JCLI3297.1.

Boer, G. J., 1993: Climate change and the regulation of the surface moisture and energy budgets. Climate Dyn., 8, 225-239, doi:10.1007/BF00198617.

Branstator, G., and H. Teng, 2012: Potential impact of initialization on decadal predictions as assessed for CMIP5 models. Geophys. Res. Lett., 39, L12703, doi:10.1029/2012GL051974.

Brown, R. D., and D. A. Robinson, 2011: Northern Hemisphere spring snow cover variability and change over 1922-2010 including an assessment of uncertainty. Cryosphere, 5, 219-229, doi:10.5194/tc-5-219-2011.

, B. Brasnett, and D. Robinson, 2003: Gridded North American monthly snow depth and snow water equivalent for GCM evaluation. Atmos.-Ocean, 41, 1-14, doi:10.3137/ao.410101.

— D. Derksen, and L. Wang, 2010: A multi-data set analysis of variability and change in Arctic spring snow cover extent, 19672008. J. Geophys. Res., 115, D16111, doi:10.1029/2010JD013975.

Brun, E., V. Vionnet, A. Boone, B. Decharme, Y. Peings, R. Valette, F. Karbou, and S. Morin, 2013: Simulation of northern Eurasian local snow depth, mass, and density using a detailed snowpack model and meteorological reanalyses. J. Hydrometeor., 14, 203-219, doi:10.1175/JHM-D-12-012.1.

Brutel-Vuilmet, C., M. Ménégoz, and G. Krinner, 2013: An analysis of present and future seasonal Northern Hemisphere land snow cover simulated by CMIP5 coupled climate models. Cryosphere, 7, 67-80, doi:10.5194/tc-7-67-2013.

Cohen, J. L., J. C. Furtado, M. A. Barlow, V. A. Alexeev, and J. E. Cherry, 2012: Arctic warming, increasing snow cover and widespread boreal winter cooling. Environ. Res. Lett., 7, 014007, doi:10.1088/1748-9326/7/1/014007.

Collins, M., and Coauthors, 2013: Long-term climate change: Projections, commitments and irreversibility. Climate Change 2013: The Physical Science Basis. T. F. Stocker et al., Eds., Cambridge University Press, 1029-1136, doi:10.1017/ CBO9781107415324.008.

Dai, A., 2008: Temperature and pressure dependence of the rainsnow phase transition over land and ocean. Geophys. Res. Lett., 35, L12802, doi:10.1029/2008GL033295.

Derksen, C., and R. Brown, 2012: Spring snow cover extent reductions in the 2008-2012 period exceeding climate model projections. Geophys. Res. Lett., 39, L19504, doi:10.1029/ 2012 GL053387.

, - L L. Mudryk, and K. Luojus, 2015: Terrestrial snow (Arctic) [in "State of the Climate in 2014"]. Bull. Amer. Meteor. Soc., 96, S133-S135. 
Déry, S. J., and R. D. Brown, 2007: Recent Northern Hemisphere snow cover extent trends and implications for the snow-albedo feedback. Geophys. Res. Lett., 34, L22504, doi:10.1029/2007GL031474.

Deser, C., R. Knutti, S. Solomon, and A. S. Phillips, 2012a: Communication of the role of natural variability in future North American climate. Nat. Climate Change, 2, 775-779, doi:10.1038/ nclimate1562.

_ A. S. Phillips, V. Bourdette, and H. Teng, 2012b: Uncertainty in climate change projections: The role of internal variability. Climate Dyn., 38, 527-546, doi:10.1007/s00382-010-0977-x.

,,-- M. A. Alexander, and B. V. Smoliak, 2014: Projecting North American climate over the next 50 years: Uncertainty due to internal variability. J. Climate, 27, 2271-2296, doi:10.1175/JCLI-D-13-00451.1.

_ L. Terray, and A. S. Phillips, 2016: Forced and internal components of winter air temperature trends over North America during the past 50 years: Mechanisms and implications. J. Climate, 29, 2237-2258, doi:10.1175/JCLI-D-15-0304.1.

Diffenbaugh, N. S., J. S. Pal, R. J. Trapp, and F. Giorgi, 2005: Finescale processes regulate the response of extreme events to global climate change. Proc. Natl. Acad. Sci. USA, 102, 15 774-15 778, doi:10.1073/pnas.0506042102.

- M. Scherer, and M. Ashfaq, 2013: Response of snowdependent hydrologic extremes to continued global warming. Nat. Climate Change, 3, 379-384, doi:10.1038/nclimate1732.

Essery, R., 1997: Seasonal snow cover and climate change in the Hadley Centre GCM. Ann. Glaciol., 25, 362-366.

— comparison of 1701 snow models using observations from an alpine site. Adv. Water Resour., 55, 131-148, doi:10.1016/ j.advwatres.2012.07.013.

Etchevers, P., and Coauthors, 2004: Validation of the energy budget of an alpine snowpack simulated by several snow models (SnowMIP project). Ann. Glaciol., 38, 150-158, doi:10.3189/ 172756404781814825.

Flanner, M. G., C. S. Zender, P. G. Hess, N. M. Mahowald, T. H. Painter, V. Ramanathan, and P. J. Rasch, 2009: Springtime warming and reduced snow cover from carbonaceous particles. Atmos. Chem. Phys., 8, 2481-2497, doi:10.5194/ acpd-8-19819-2008.

_ K. M. Shell, M. Barlage, D. K. Perovich, and M. A. Tschudi, 2011: Radiative forcing and albedo feedback from the Northern Hemisphere cryosphere between 1979 and 2008. Nat. Geosci., 4, 151-155, doi:10.1038/ngeo1062.

Flato, G., and Coauthors, 2013: Evaluation of climate models. Climate Change 2013: The Physical Science Basis, T. F. Stocker et al., Eds., Cambridge University Press, 741-866.

Fletcher, C. G., P. J. Kushner, A. Hall, and X. Qu, 2009: Circulation responses to snow albedo feedback in climate change. Geophys. Res. Lett., 36, L09702, doi:10.1029/2009GL038011.

Groisman, P., T. R. Karl, R. W. Knight, and G. L. Stenchikov, 1994: Changes of snow cover, temperature, and radiative heat balance over the Northern Hemisphere. J. Climate, 7, 1633-1656, doi:10.1175/1520-0442(1994)007<1633:COSCTA > 2.0.CO;2.

Hall, A., 2004: The role of surface albedo feedback in climate. J. Climate, 17, 1550-1568, doi:10.1175/1520-0442(2004)017<1550: TROSAF $>2.0 . \mathrm{CO} ; 2$.

— , X. Qu, and J. D. Neelin, 2008: Improving predictions of summer climate change in the United States. Geophys. Res. Lett., 35, L01702, doi:10.1029/2007GL032012.

Hall, D. K., 1988: Assessment of polar climate change using satellite technology. Rev. Geophys., 26, 26-39, doi:10.1029/ RG026i001p00026.
Hansen, J., R. Ruedy, M. Sato, and K. Lo, 2010: Global surface temperature change. Rev. Geophys., 48, RG4004, doi:10.1029/ 2010RG000345.

Hawkins, E., and R. Sutton, 2009: The potential to narrow uncertainty in regional climate predictions. Bull. Amer. Meteor. Soc., 90, 1095-1107, doi:10.1175/2009BAMS2607.1.

— and - 2011: The potential to narrow uncertainty in projections of regional precipitation change. Climate Dyn., 37, 407-418, doi:10.1007/s00382-010-0810-6.

Hegerl, G. C., and Coauthors, 2007: Understanding and attributing climate change. Climate Change 2007: The Physical Science Basis, S. Solomon et al., Eds., Cambridge University Press, 663-745.

Hernández-Henríquez, M. A., S. J. Déry, and C. Derksen, 2015: Polar amplification and elevation-dependence in trends of Northern Hemisphere snow cover extent, 1971-2014. Environ. Res. Lett., 10, 044010, doi:10.1088/1748-9326/10/4/044010.

Ingram, W. J., C. A. Wilson, and J. F. B. Mitchell, 1989: Modeling climate change: An assessment of sea ice and surface albedo feedbacks. J. Geophys. Res., 94, 8609-8622, doi:10.1029/ JD094iD06p08609.

Jones, P. D., M. New, D. Parker, S. Martin, and I. G. Rigor, 1999: Surface air temperature and its changes over the past 150 years. Rev. Geophys., 37, 173-199, doi:10.1029/1999RG900002.

_ D. H. Lister, T. J. Osborn, C. Harpham, M. Salmon, and C. P. Morice, 2012: Hemispheric and large-scale land-surface air temperature variations: An extensive revision and an update to 2010. J. Geophys. Res., 117, D05127, doi:10.1029/2011JD017139.

Kalnay, E., and Coauthors, 1996: The NCEP/NCAR 40-Year Reanalysis Project. Bull. Amer. Meteor. Soc., 77, 437-471, doi:10.1175/1520-0477(1996)077<0437:TNYRP>2.0.CO;2.

Karl, T. R., P. Ya. Groisman, R. W. Knight, and R. R. Heim, 1993: Recent variations of snow cover and snowfall in North America and their relation to precipitation and temperature variations. J. Climate, 6, 1327-1344, doi:10.1175/ 1520-0442(1993)006<1327:RVOSCA >2.0.CO;2.

Kay, J. E., and Coauthors, 2015: The Community Earth System Model (CESM) Large Ensemble Project: A community resource for studying climate change in the presence of internal climate variability. Bull. Amer. Meteor. Soc., 96, 1333-1349, doi:10.1175/BAMS-D-13-00255.1.

Krasting, J. P., A. J. Broccoli, K. W. Dixon, and J. R. Lanzante, 2013: Future changes in Northern Hemisphere snowfall. J. Climate, 26, 7813-7828, doi:10.1175/JCLI-D-12-00832.1.

Laliberté, F., S. E. L. Howell, and P. J. Kushner, 2016: Regional variability of a projected sea ice-free Arctic during the summer months. Geophys. Res. Lett., 43, 256-263, doi:10.1002/ 2015 GL066855.

Lawrence, D. M., and A. G. Slater, 2010: The contribution of snow condition trends to future ground climate. Climate Dyn., $\mathbf{3 4}$ 969-981, doi:10.1007/s00382-009-0537-4.

,-- , and S. C. Swenson, 2012: Simulation of present-day and future permafrost and seasonally frozen ground conditions in CCSM4. J. Climate, 25, 2207-2225, doi:10.1175/ JCLI-D-11-00334.1.

Levis, S., G. B. Bonan, and P. J. Lawrence, 2007: Present-day springtime high-latitude surface albedo as a predictor of simulated climate sensitivity. Geophys. Res. Lett., 34, L17703, doi:10.1029/2007GL030775.

Manabe, S., and R. T. Wetherald, 1987: Large-scale changes of soil wetness induced by an increase in atmospheric carbon dioxide. J. Atmos. Sci., 44, 1211-1236, doi:10.1175/ 1520-0469(1987)044<1211:LSCOSW>2.0.CO;2. 
Mankin, J. S., and N. S. Diffenbaugh, 2015: Influence of temperature and precipitation variability on near-term snow trends. Climate Dyn., 45, 1099-1116, doi:10.1007/s00382-014-2357-4.

_ , D. Viviroli, D. Singh, A. Y. Hoekstra, and N. S. Diffenbaugh, 2015: The potential for snow to supply human water demand in the present and future. Environ. Res. Lett., 10, 114016, doi:10.1088/ 1748-9326/10/11/114016.

Meehl, G. A., and Coauthors, 2007: Global climate projections. Climate Change 2007: The Physical Science Basis, S. Solomon et al., Eds., Cambridge University Press, 747-846.

Mudryk, L. R., P. J. Kushner, and C. Derksen, 2014: Interpreting observed Northern Hemisphere snow trends with large ensembles of climate simulations. Climate Dyn., 43, 345-359, doi:10.1007/s00382-013-1954-y.

— C. Derksen, P. J. Kushner, and R. Brown, 2015: Characterization of Northern Hemisphere snow water equivalent datasets, 19812010. J. Climate, 28, 8037-8051, doi:10.1175/JCLI-D-15-0229.1.

Peters, G. P., and Coauthors, 2013: The challenge to keep global warming below $2^{\circ} \mathrm{C}$. Nat. Climate Change, 3, 4-6, doi:10.1038/ nclimate1783.

Pithan, F., and T. Mauritsen, 2014: Arctic amplification dominated by temperature feedbacks in contemporary climate models. Nat. Geosci., 7, 181-184, doi:10.1038/ngeo2071.

Qu, X., and A. Hall, 2014: On the persistent spread in snow-albedo feedback. Climate Dyn., 42, 69-81, doi:10.1007/s00382-013-1774-0.

Räisänen, J., 2008: Warmer climate: Less or more snow? Climate Dyn., 30, 307-319, doi:10.1007/s00382-007-0289-y.

Rienecker, M. M., and Coauthors, 2011: MERRA: NASA's ModernEra Retrospective Analysis for Research and Applications. J. Climate, 24, 3624-3648, doi:10.1175/JCLI-D-11-00015.1.

Robinson, D., and A. Frei, 2000: Seasonal variability of Northern Hemisphere snow extent using visible satellite data. Prof. Geogr., 52, 307-315, doi:10.1111/0033-0124.00226.

Rodell, M., and Coauthors, 2004: The Global Land Data Assimilation System. Bull. Amer. Meteor. Soc., 85, 381-394, doi:10.1175/ BAMS-85-3-381.

Roesch, A., 2006: Evaluation of surface albedo and snow cover in AR4 coupled climate models. J. Geophys. Res., 111, D15111, doi:10.1029/2005JD006473

Rutter, N., and Coauthors, 2009: Evaluation of forest snow processes models (SnowMIP2). J. Geophys. Res., 114, D06111, doi:10.1029/2008JD011063.

Scott, D., J. Dawson, and B. Jones, 2008: Climate change vulnerability of the US Northeast winter recreation-tourism sector. Mitig. Adapt. Strategies Global Change, 13, 577-596, doi:10.1007/ s11027-007-9136-z.

Shi, H. X., and C. H. Wang, 2015: Projected 21st century changes in snow water equivalent over Northern Hemisphere landmasses from the CMIP5 model ensemble. Cryosphere, 9, 1943-1953, doi:10.5194/tc-9-1943-2015.

Slater, A. G., and Coauthors, 2001: The representation of snow in land surface schemes: Results from PILPS 2(d). J. Hydrometeor., 2, 7-25, doi:10.1175/1525-7541(2001)002<0007: TROSIL $>2.0 . \mathrm{CO} ; 2$

Smith, T. M., R. W. Reynolds, T. C. Peterson, and J. Lawrimore, 2008: Improvements to NOAA's historical merged landocean surface temperature analysis (1880-2006). J. Climate, 21, 2283-2296, doi:10.1175/2007JCLI2100.1.

Swart, N. C., J. C. Fyfe, E. Hawkins, J. E. Kay, and A. Jahn, 2015: Influence of internal variability on Arctic sea-ice trends. Nat. Climate Change, 5, 86-89, doi:10.1038/nclimate2483.

Takala, M., K. Luojus, J. Pulliainen, C. Derksen, J. Lemmetyinen, J.-P. Kärnä, J. Koskinen, and B. Bojkov, 2011: Estimating Northern Hemisphere snow water equivalent for climate research through assimilation of space-borne radiometer data and ground-based measurements. Remote Sens. Environ., 115, 3517-3529, doi:10.1016/j.rse.2011.08.014.

Taylor, K. E., R. J. Stouffer, and G. A. Meehl, 2012: An overview of CMIP5 and the experiment design. Bull. Amer. Meteor. Soc., 93, 485-498, doi:10.1175/BAMS-D-11-00094.1.

Thackeray, C. W., and C. G. Fletcher, 2016: Snow albedo feedback: Current knowledge, importance, outstanding issues and future directions. Prog. Phys. Geogr., 40, 392-408, doi:10.1177/ 0309133315620999.

, and C. Derksen, 2015: Quantifying the skill of CMIP5 models in simulating seasonal albedo and snow cover evolution. J. Geophys. Res. Atmos., 120, 5831-5849, doi:10.1002/ 2015JD023325.

Turner, J., W. M. Connolley, T. A. Lachlan-Cope, and G. J. Marshall, 2006: The performance of the Hadley Centre climate model (HadCM3) in high southern latitudes. Int. J. Climatol., 26, 91-112, doi:10.1002/joc.1260.

Westerling, A. L., H. G. Hidalgo, D. R. Cayan, and T. W. Swetnam, 2006: Warming and earlier spring increase western U.S. forest wildfire activity. Science, 313, 940-943, doi:10.1126/science.1128834.

Wettstein, J. J., and C. Deser, 2014: Internal variability in projections of twenty-first-century Arctic sea ice loss: Role of the large-scale atmospheric circulation. J. Climate, 27, 527-550, doi:10.1175/JCLI-D-12-00839.1.

Zhang, T., 2005: Influence of the seasonal snow cover on the ground thermal regime: An overview. Rev. Geophys., 43, RG4002, doi:10.1029/2004RG000157.

, R. G. Barry, K. Knowles, J. Heginbottom, and J. Brown, 2008: Statistics and characteristics of permafrost and groundice distribution in the Northern Hemisphere. Polar Geogr., 31, 47-68, doi:10.1080/10889370802175895. 